Global Conferences Series:

Sciences and Technology (GCSST), Volume 3, 2020

The $1^{\text {st }}$ International Conference on Education, Sciences and Technology

DOI: https://doi.org/10.32698/tech3234

\title{
Does Work Motivation Mediate the Effect of Individual Values on Organizational Commitment?
}

\author{
AMahmud $^{1}$, NSusilowati ${ }^{1}$, and TTusyanah ${ }^{1}$ \\ ${ }^{1}$ Faculty of Economics, UniversitasNegeri Semarang \\ Sekaran Campus, Gunungpati, Semarang, Indonesia, 50229 \\ amirmahmud@mail.unnes.ac.id
}

\begin{abstract}
The objective of the study is toanalyzehuman values model to determine lecturers' individual values, work motivation, and organizational commitmentat UniversitasNegeri Semarang. The independent variable of this study is individual values, the intervening variable is work motivation, and the dependent variable is organizational commitment. This study used a proportionate random sampling technique to obtain samples of 324 lecturers. The data were collected by distributing the questionnaires and then were analyzed using path analysis. The results of the study were; first, work motivation could directly influence organizational commitment. Second, work motivation successfully mediated the influence of individual values on organizational commitment. Third, individual values did not influence organizational commitment. Good individual values are indicated by each lecturer. However, the fact shows that individual values cannot be changed instantly sincesomeone may show the good things but he/ she may not be accompanied by the good organizational commitment.
\end{abstract}

Keywords.individual values, work motivation, organizational commitment, lecturers

\section{Introduction}

The payment given to lecturers based on the principles of suitability, justice, interest, and realism may not necessarily improve the organizational commitment of lecturers, and evaluation of the directed amounts to be received by each lecturer is still required. Precisely directed payment may improve the lecturers' organizational commitment. This is even more so with globalization, which brings about individual fragility in facing organizations that become more and more competitive. One of the challenges is to obtain organizational commitment in the form of human capital [1][2].

Organizational commitment is a dynamic process that must be continuously performed. Administrators then can measure the level of commitment in an organization and create strategies for strengthening or improvement [3]. Organizational commitment, according to [4], has many forms and may influence organizational capacity and lecturer welfare. Organizational commitment may also determine various lecturers'behaviours. One of the strategies to create good organizational commitment is by motivating lecturers, which will then improve organizational performance [5][6]. Individual values become the bases for and encourages the achievement of working goals and the working environment [7]. Individual values can direct behaviours, encourage individuals, and may provide justification on individual behaviours.

The first factor that may influence organizational commitment is individual values. [8] stated that individual values become the base for the achievement of the goals of an organization. It means

Copyright $($ C 2019, the Authors. Published by Redwhite Press.

Page $\mid 44$

This is an open access article under the CC BY-NC license

(http://creativecommons.org/licenses/by-nc/4.0). 
that there are effects from individual values on organizational commitment. Individual values guide and direct actions, behaviours, and the judgment of people [9]. Individual values are a basic component that may provide motivation and control individual behaviour for the achievement of organizational goals. Individual values have a relationship with motivation. As such, there is an indirect effect from individual values on organizational commitment through the work motivations of lecturers.

[10] explained that the working motivations of employees very much determine the achievement of organizational goals. The motivation is determined by individual values [11]. These values establish certain goals and guide the actions that must be taken. In addition, this relationship can also be understood as a goal that is achieved according to the realization of values and the form of values of needs that must be fulfilled. Therefore, organizations that wish to maintain competitiveness and continuity need to consider individual motivation as an important element in making up organizational commitment and achieving better performance as well as productivity.

Based on the above explanation, the study will construct and test the effect of individual values and work motivation on organizational commitment. To achieve the overall objective, it is necessary to evaluate the construction composed of the hypothetical model proposed in the study that is judged to be salient, by identifying different individuals according to individual values; to verify the associative relationships of each individual according to the hypothesis structural variables suggested by the model; and to verify the validity and appropriateness of the proposed hypothesis using the structural model.

\section{Literature Review and Hypothesis Development}

Organizational commitment can determine various lecturers'behaviours. One of the strategies to create good organizational commitment is by motivating lecturers toimprove organizational performance [6]. The motivation is determined by individual values [11]. These establish certain goals and guide actions that must be taken. In addition, this relationship can also be understood as a goal achieved according to the realization of values and the form of values of needs that must be fulfilled. As such, organizations that would like to remain competitive and continuous need to consider individual motivation as an important element of organizational commitment and for achieving better performance as well as productivity. Thus; it is hypothesized that;

\section{$H_{1}$ :There is a direct effect of human values on organizational commitment.}

Human values [12] are a factor that very much determines the continuity of organizations and individuals. Human values are the foundation that forms individual behaviours in a society. The human values model explains about the concept of individual values, motivation, commitment, and reward that influences organizational performance. That individual values have a basic function in motivating and controlling individual behaviours. Motivation and control of behaviours have a relationship in groups or among individuals in society. Individual values are a component of organizational values that strengthen organizational commitment. Then, organizational commitment, according to [13], has many forms and may influence organizational capacity and lecturer welfare. Organizational commitment may also be a determinant of various lecturer behaviours. Thus; the second hypothesis is;

\section{$\mathrm{H}_{2}$ :There is an indirect effect ofindividual values on organizational commitment through work motivation.}

Individual values have the basic function of motivating and controlling individual behaviours. [7], in line with [14] and [10], added that behaviours are initiated and motivated by unconscious objectives according to the situation or environment. In the study, the primary theory of motivation, according [15] and [16], is based on the hypothesis structural model that covers the study and questionnaire composition. In short, organizational performance is influenced by motivation. Thus; the third hypothesis is;

\section{$\mathrm{H}_{3}$ : There is a direct effect of work motivation on organizational commitment.}

Based on the grand theory and results of prior research, the design ofthe study can be seen at figure 1 . 


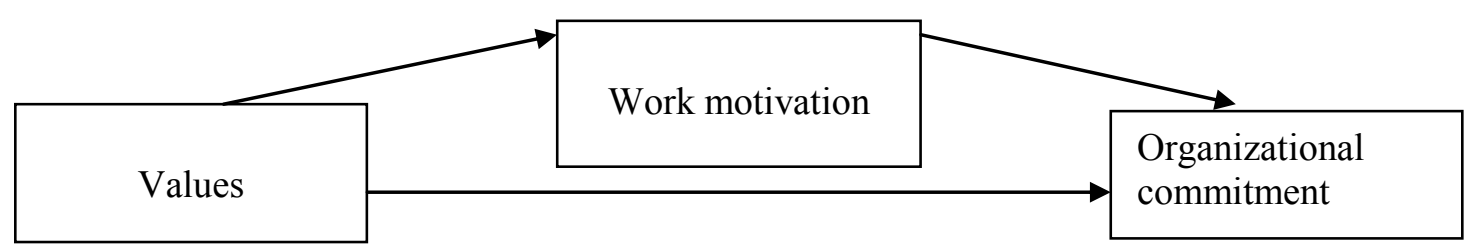

Figure 1. Conceptual Framework

\section{Method}

\subsection{Research Design and Procedure}

It is a quantitative research. The population of the studyareall lecturers at Universitas Negeri Semarang, they are 324 lecturers. The total samples are calculated withSlovin formula in Husein[17].Then, samples are taken by using the random sampling technique.

The first variable in the study is values. Individual values are values that determine behaviours or actions, with the indicators of self-enhancement, openness to changes, self-transcendence, and conservation [9]. The second variable is work motivation, which is the reaction to do certain things and to move in certain directions, with the indicators of desire to do work, strive in work, and energy to push in work as developed by [14] and [7]. The third variable is organizational commitment, which is the psychological state that relates individuals and organizations, with the affective, instrumental, regulatory, and professional indicators as developed [13].

\subsection{Techniques of Collecting and Analyzing Data}

The data are collected by distributing questionnaires, which were then analyzed using path analysis. The distribution of questionnaires for the collection of data in the study was conducted using Google Forms. The utilized method of data analysis is path analysis. Path analysis is a method of statistical analysis that allows providing a quantitative interpretation of the relationship among a number of variables and models. The objective of path analysis here is to determine direct effects and indirect effects among a number of variables.

\section{Result and Discussion}

\subsection{Research Findings}

The results of hypotheses can be seen in the table of regression weights as displayed in Table 1 and 2 . From Table 2, it is known that there are two accepted hypotheses, indicated by the significance value in column $\mathrm{P}$ being less than 0.05 . The three asterisks indicate that the $\mathrm{p}$-value is less than 0.001 . Furthermore; there is one hypothesis is rejected, indicated by the significance value being greater than 0.05. The size of the influence among variables can be known from the table of standardized regression weights. The estimate column indicates the size of the influence among variables. It is known that individual values significantly influence work motivation for $72.3 \%$. Then, work motivation influences organizational commitment for $38.8 \%$. Individual values were found not to influence organizational commitment.

Table 1. Regression Weights: (Group number 1 - Default model)

\begin{tabular}{|c|c|c|c|c|c|c|c|}
\hline Variables & & Variables & $\begin{array}{l}\text { Estim } \\
\text { ate }\end{array}$ & S.E. & C.R. & $\mathbf{P}$ & Label \\
\hline $\begin{array}{l}\text { Work } \\
\text { Motivation }\end{array}$ & $<--$ & Values & 0.595 & 0.051 & $\begin{array}{l}11.6 \\
77\end{array}$ & $* * *$ & Significant \\
\hline $\begin{array}{l}\text { Organization } \\
\text { al } \\
\text { Commitment }\end{array}$ & $<--$ & Values & -0.002 & 0.127 & -.019 & 0.984 & $\begin{array}{l}\text { Insignifican } \\
\mathrm{t}\end{array}$ \\
\hline $\begin{array}{l}\text { Organization } \\
\text { al } \\
\text { Commitment }\end{array}$ & $<--$ & $\begin{array}{l}\text { Work } \\
\text { Motivation }\end{array}$ & 0.586 & 0.162 & $\begin{array}{l}3.61 \\
0\end{array}$ & $* * *$ & Significant \\
\hline
\end{tabular}


Table 2. Standardized Regression Weights: (Group number 1 - Default model)

\begin{tabular}{llll}
\hline \multicolumn{1}{c}{ Variables } & & \multicolumn{1}{c}{ Variables } & \multicolumn{1}{c}{ Estimate } \\
\hline WorkMotivation & $<---$ & Values & .723 \\
OrganizationalCommitment & $<---$ & Values & -.002 \\
\hline OrganizationalCommitment & $<---$ & WorkMotivation & .388 \\
\hline
\end{tabular}

To find out whether there is indirect effect in the created model, significance testing of indirect effects was performed using the Sobel test. The result shows that two-tailed probability value is 0.01 (less than 0.05), and therefore hypothesis 2 is accepted. It means there is an indirect effect of individual values on the organizational commitment of lecturers through work motivation. The size of the indirect effect can be seen in Table 3 below. The indirect effect of individual values on organizational commitment through work motivation was $34.9 \%$.

Table 3. Summary of Hypothesis Results

\begin{tabular}{lllll}
\hline No & Hypothesis & P Value & $\begin{array}{l}\text { Standardized } \\
\text { Coefficient } \\
\text { Parameter }\end{array}$ & Results \\
\hline 1 & $\begin{array}{l}\text { There is a direct effect of values on } 0.984 \\
\text { organizational commitment. }\end{array}$ & -0.002 & Rejected \\
\hline 2 & $\begin{array}{l}\text { There is an indirect effect of } 0.018 \\
\text { individual values on organizational } \\
\text { commitment through work } \\
\text { motivation. }\end{array}$ & 0.349 & Accepted \\
\hline 3 & $\begin{array}{l}\text { There is a direct effect of work } 0.000 \\
\text { motivation on organizational } \\
\text { commitment. }\end{array}$ & 0.388 & Accepted \\
\hline
\end{tabular}

\subsection{Discussion}

\subsubsection{Direct Effect of Individual Values on Organizational Commitment}

Based on the results of the research, individual values do not have a direct effect on the organizational commitment of lecturers. Descriptively, the individual values are already satisfactory and organizational commitment is quite good. Fundamentally, good individual values have been shown by each lecturer. However, in reality, individual values cannot be instantly changed, since although individual values may show good things, they may not be accompanied by good organizational commitment. Therefore, based on the results of the research, it was also found that individual values do not influence organizational commitment.

Based on the theory of the human values model, individual values are a component of organizational values that strengthen organizational commitment. Individual values also become the bases for the achievement of organizational [8]. However, the human values model theory also states that individual living values may also be influenced by the society and personal experiences, which is evidenced by attitudes on those experiences. Thus, individual values do not directly influence organizational commitment.

The phenomenon that occurs in the office of lecturers is that the values that have applied to the life of lecturers are not able to influence the formation of organizational commitment. For example, a lecturer who indeed has a good internal character will have a strong commitment to the organization. On the other hand, a lecturer who indeed has a bad internal character, for example by not showing up even when there are no scheduled courses, will tend to have organizational commitment that tends to remain as it is, or is even undeveloped. This is since individual values have fundamentally applied to them, and thus to change these people to be able to have a firm grasp of commitment on an organization, the process requires a long time and cannot be done instantly. 


\subsubsection{Indirect Effect of Individual Values on Organizational Commitment through Work Motivation}

Based on the results of the research, individual values have an effect on organizational commitment through work motivation. One of the strategies to create good organizational commitment is to motivate lecturers toimprove organizational performance [5][6]. That motivation is determined by individual values. They establish specific goals and guide the necessary course of actions [11]. Furthermore, this relationship can also mean that the objective to be achieved is to be in line with the realization of values and the form of values of needs that have to be fulfilled. Descriptively, values, work motivation, and organizational commitment of lecturers are already good. The research results are in line with the views [9], who stated that the basic functions of individual values are to motivate and control individual behaviours. [7] also add that individual behaviour becomes the basis for and encourages the achievement of work goals and the work environment. [10] also explain that the work motivation of employees very much determines the achievement of organizational goals. Therefore, organizations that wish to stay competitive and continuous need to consider individual motivation as an important element in creating organizational commitment and achieving better performance and productivity.

Motivation from the surrounding environment may form and change the values that have applied to individuals to be able to contribute and be committed to the organization. Motivation gained from the will to work, hard work, and strength to work can empower individual values to be able to commit to the organization.

The human values model theory states that individual values are believed to be linked to the loyalty to achieve the desired objectives. The achievements of these objectives are also supported by the motivation to behave well in every action and situation to be able to commit to provide contributions to the organization to achieve its goals. This is also in line with the views of [12] who stated that individual values are factors that very much determine the continuity of organizations and individuals.

\subsubsection{Direct Effect of Work Motivation on Organizational Commitment}

Based on the results of the research, work motivation has an influence on the organizational commitment of lecturers. This is in line with the views of [5] and [6], which is that one of the strategies to create good organizational commitment is by motivating lecturers to improve organizational performance. Organizations that wish to retain their competitiveness and continuity need to consider individual motivation as an important element in creating organizational commitment and achieving better performance and productivity. Descriptively, lecturers have already possessed good motivation as well as organizational commitment. From the results of the study, it can be reasoned that if lecturers are motivated, they will be more committed to the organization.

The organizational commitment embedded in lecturers are indicated by everyday behaviours and contributions provided to the organization. The behaviours that lecturers demonstrate are not only formed by internal motivation, but also organization climate and colleagues. This is also in line with the views [7][14][10] who add that behaviours are incited and motivated by unconscious objectives, according to the situation or environment.

\section{Conclusion}

It is concluded that; first, individual values do not have a direct effect on organizational commitment. Individual values are a component of organizational value which strengthens organizational commitment. Individual values also become the bases for the achievement of organizational goals. Next; work motivation mediates the influence of values on organizational commitment. Individual motivation is an important element in increasing organizational commitment and organizational productivity. Third, work motivation directly influences organizational commitment. It means that work motivation drives individuals to work well to achieve organizationalobjectives. 


\section{References}

[1] Gracioli, C., Godoy, L.P., Lorenzett, D.B. and Godoy, T.P. Intellectual capital: an innovative tool in the search for competitive advantages. Journal of Business Administration and Innovation, 2012,Vol. 9 No. 4, pp. 96-120.

[2] Kéelwalatenna, S. and Premaratne, G.An empirical investigation into the behavior of intellectual capital.IUP Journal of Knowledge Management.2013,Vol. 11 No. 1, pp. 38-57.

[3] Liou, S.An analysis of the concept of organizational commitment.Nursing Fórum,2008, Vol. 43 No. 3, pp. 116-124.

[4] Meyer, J.P. and Herscovitch, L. Commitment in the workplace: on a general model. Human Resource Management Review. 2001, Vol. 11 No. 3, pp. 299-326.

[5] Alonso, P. and Lewis, G.B. Public service motivation and job performance evidence from the federal sector. The American Review of Public Administration. 2001,Vol. 31 No. 4, pp. 363-380.

[6] Patall, E.A. The motivational complexity of choosing: a review of theory and research. Oxford Handbook of Human Motivation.Oxford University Press, Oxford. 2012. pp. 248-279.

[7] Park, S.M. and Word, J. Driven to service: intrinsic and extrinsic motivation for public and nonprofit managers", Public Personnel Management.2012,Vol. 41 No. 4, pp. 705-734.

[8] Schwartz, S. H., Sagiv, L., \&Boehnke, K. Worries andvalue.Journal of personality. 2000, 68, 309-346.

[9] Schwartz SI, Shires GT, Spencer FC, Daly JM, Fischer JE, Galloway AC. Principles of Surgery. United States of America : McGraw-Hill companies; 2012

[10] Aarts, H. and Custers, R. Unconscious goal pursuit: non-conscious goal regulation and motivation. Oxford Handbook of Human Motivation. Oxford University Press, Oxford, 2012, pp. 85-107.

[11] Schunk, Dale. H. Learning Theories: An Educational Perspectives, 6th Edition. New York: Pearson Education Inc. 2012

[12] Medeiros, E.D., Gouveia, V.V., Gusmão, E.E.S., Milfont, T.L. and Aquino, A.A. Functionalist theory of human values: evidence of their suitability in connection with Brazil. Mackenzie Administration Magazine. 2012, Vol. 13 No. 3, pp. 18-44.

[13] Meyer, J., Becker, T. and Vandenberghe, C. Employee commitment and motivation: a conceptual analysis and integrative model. Journal of Applied Psychology. 2004, Vol. 89 No. 6, pp. 9911007.

[14] Aworemi, J.R., Abdul-Azeez, I.A. and Durowoju, S.T.An empirical study of the motivational factors of employees in Nigeria.International Journal of Economics \& Finance. 2011, Vol. 3 No. 5, pp. 227-233.

[15] Bowditch, J.L. and Buono, A.F. Fundamentals of Organizational Behavior, LTC, Rio de Janeiro. 2006

[16] Hitt, M.A., Muller, C.C. and Colella, A. Organizational Behavior: A Strategic Approach, LTC, Rio de Janeiro. 2007

[17] Riduan\&Kuncoro.CaraMenggunakandanMemakai Path Analysis (AnalisisJalur). Bandung: Alfabeta. 2011 